\title{
Effect of progesterone hormon on cell viability and stem cell activation in dental pulp cells
}

\section{Progesteron hormonunun diş pulpa hücrelerinde hücre yaşamına ve kök hücre aktivasyonuna etkileri}

\author{
Segah Altuntaş ${ }^{1}$, Muhammed Ali Kara $^{2}$, Deniz Selin Aksoy ${ }^{1}$, Zehra Dilşad Çoban $^{3}$, \\ Şe filk Güiran ${ }^{3}$ \\ ${ }^{a}$ Workers have contributed equally to the project.
}

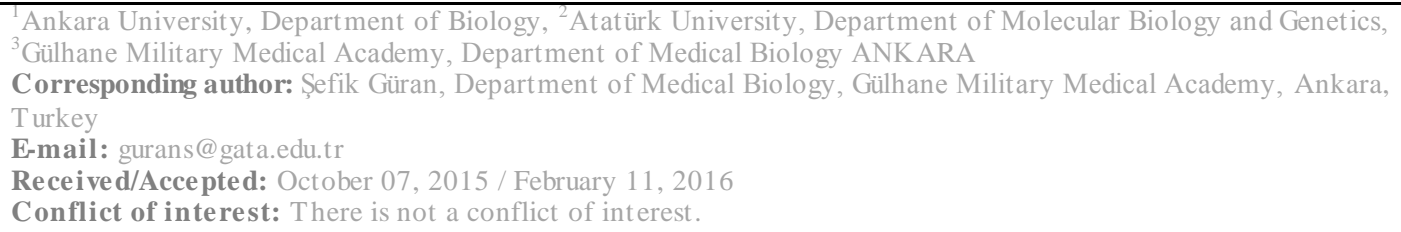

\begin{abstract}
SUMMARY
Objective: The dental pulp is the part in the center of a tooth made up of living connective tissue and cells called odontoblasts. The vitality of the dentin structure, both during health and after injury, depends on pulp cell activity and the signaling processes that regulate the cell's behavior. Dental pulp tissue has condensed stem cell activity. Dental pulp stem cells are multipotent stem cells that have the potential to differentiate into a variety of cell types. Several publications have stressed the importance of the expression of pluripotentiality as sociated markers: the transcription factors Nanog, Sox2, Oct3/4, SSEA4, CD13, Stro1 are indispensable for the stem cells to divide indefinitely without affecting their differentiation potential (self renewal) capacity. Progesterone is a steroid hormone leading to menstrual cycle and gestation. There is a widespread rumor among people that pregnancy causes toothy loss.
\end{abstract}

Method: So, progesterone was applied in different concentrations on human dental pulp cells in cell culture. Cell viability assay was applied $24^{\text {th }}$ hour later with trypan blue. RNA isolation, cDNA synthesis and Real Time PCR analysis were applied on selected transcription factors (Nanog and Oct4 (POU5F1) genes) which have role on steamness of stem cells. Gene expression analyses results were correlated with the cell viability assay results.

Results: Cell viability assay results were $80 \%$ viable in control, $82 \%$ viable in $7 \mathrm{ml}$ progesterone application, $81 \%$ viable in $14 \mathrm{ml}$ progesterone application, $83 \%$ viable in $21 \mathrm{ml}$ progesterone application. Due to our findings, progesterone in different concentrations did not chance the cell viability in dental pulpa cells. On gene expression analyses, preliminary results supported that high concentrations of progesterone enhance the gene expressions of steamness genes (Nanog, and Oct4) in dental pulp cells.

Conclusions: So, progesterone did not change cell viability in high concentrations. We assume that progesterone did not affect apopitotic pathways on dental pulp cells. On the other hand, high gene expressions of Nanog, and Oct4 in high doses of progesterone represent the importance of progesterone hormone in dental pulp cells including stem cells maintenance.

Key words: Dental pulp tissue, Stemness, Nanog, Oct4(POU5F1). 
ÖZET

Amaç: Diş pulpa dişin merkezinde olan konnektif doku ve odontoblast hücrelerden oluşan yapıdır. Diş sağlam veya yaralanmışken dentin yapısının canlılığına hücre sinyal aktivitelerine bağlıdır. Bu yap1 yoğun kök hücre aktivitesine sahiptir. Diş pulpa kök hücreleri multipotent yapıdadır ve birçok hücreye farklanır. Birçok yayın kök hücrelerin farklanmadan bölünme (self renewal) kapasitesi ile ilgili Nanog, Sox 2, Oct³/4,SSEA4, CD13, Strol gibi transkripsiyonel faktörlerinin önemini ortaya koymaktadır. Progesteron adet döngüsü ve hamilelikte önemli bir hormondur. Halk arasında hamileliklerin diş kaybına neden olduğu yönünde yaygın bir inanış vardır.

Yöntem: Progesterone hücre kültüründeki diş pulpa hücrelerine uyguland1. "Trypan blue" ile 24 saat sonrası hücre yaşaması ile ilgili deney yapıldı. RNA izolasyonu, c-DNA sentezi ve Real Time PCR analizi ile kök hücrelerin köklülük özelliklerini gösteren transkripsiyon faktörleri [Nanog, ve Ocťs (POU5F1) genleri] çalışıld1. Gen ekspresyon analizi sonuçlan hücre yaşaması ile ilgili deney sonuçları ile karşıllaştırıldı.

Bulgular: Hücre canlılık oranını gösteren tripan blue testinde; kontrol hücrelerinde \% $\% 8,7 \mu 1$ Progesteron uygulanan grupta \%82, $14 \mu \mathrm{l}$ Progesteron uygulanan grupta \%81 ve $21 \mu 1$ Progesteron eklenen grupta ise \%83 oranında canlı hücre saptandı. Bu sonuçlara göre, farklı konsantrasyonlarda progesteron diş pulpa hücrelerinin canlılık oranlarını değiștirmemektedir. Gen ekspresyon analizlerinde ilk sonuçlar yüksek doz progesteronun diş dokusunda köklülük ile ilgili genlerin (Nanog ve Oct³/4) gen ekspresyonlarını arttırdığ1, dental pulpa hücrelerini etkilediklerini ortaya koydu.

Sonuç: $\mathrm{Bu}$ sonuçlara göre Progesteron yüksek konsantrasyonlarda hücre canlılik oranını değiştirmemektedir. Biz progesteronun diş pulpa hücrelerinde apopitotik yolakları etkilemediğini düşünüyoruz. Diğer taraftan Nanog ve Oct4 gen ekspresyonunun yüksek Progesteron konsantrasyonlarında artmış olması kök hücreleri de içeren dental pulpa hücrelerinin devamlılığında progesteron varlığının önemini ortaya koymaktadır.

Anahtar sözcükler: Diş pulpa dokusu, Köklülük, Nanog, Oct³/4 (POU5F1).

\section{INTRODUCTION}

The dental pulp is the part in the center of a tooth made up of living connective tissue and cells called odontoblasts. The vitality of the dentin structure, both during health and after injury, depends on pulp cell activity and the signaling processes that regulate the cell's behavior. Dental pulp tissue has condensed stem cell activity. Dental Pulp Stem Cells, or (DPSCs) are multipotent stem cells that have the potential to differentiate into a variety of cell types. There are various studies where the importance of these cells and their regenerative capacity has been demonstrated ${ }^{1}$.

Several publications have stressed the importance of the expression of pluripotentiality associated markers: the transcription factors Nanog, Sox2, Oct $3 / 4$, SSEA4, CD13, Stro 1 are indispensable for the stem cells to divide indefinitely without affecting their differentiation potential, i.e., maintaining their selfrenovation capacity. The quantification of protein expression levels in these cells is very important in order to know their pluripotent levels, as described in some publications ${ }^{2}$.

Progesterone is an endogenous steroid hormone involved in the menstrual cycle, pregnancy, and embryogenesis of humans and other species ${ }^{3}$. In human, progesterone hormone is a steroid hormone leading to menstrual cycle and gestation. Progesterone is high in blood especially in pregnant women. Progesteron inhibits estrogen receptors and stimulates cell differentiation. Progesterone has a number of physiological effects that are amplified in the presence of estrogens. Estrogen through estrogen receptors up regulates the expression of progesterone receptors. Progesterone inhibits estrogen receptors and stimulates cell differentiation $^{4}$. There is a widespread rumor among people that pregnancy causes toothy loss ${ }^{5}$ So, progesterone may have effect on dental pulpa cells.

In our research, the effect of progesterone on dental pulpa stem cells viability and the expression changes of Nanog and 
$O c t^{3 / 4}$ in dental pulp cells were analyzed in different concentrations. Dental pulp cells, taken from healthy third molar tooth were cultured and as a hormone progesterone was applied in different concentrations. $24^{\text {th }}$ hour later, cell viability was analyzed by using trypan blue. RNA isolation, c-DNA synthesis and Real time Polymerase Chain Reaction (RT-PCR) analyses are still continuing. Due to our further results, the effect of progesterone on dental pulpa cells will be discussed.

\section{MATERIAL and METHODS}

\section{Preparing progesterone:}

Progesterone was obtained directly from the producing company (Progestan 50 $\mathrm{mg} / \mathrm{ml}$ I.M- Kodak-Farma). It was applied in different concentrations $(7 \mu \mathrm{l}, 14$ $\mu l, 21 \mu l)$ cell cultures ${ }^{6}$.

\section{Cell Culture:}

Human dental pulpa cells (kindly provided by Dr. Deniz Torun) were cultured and incubated in RPMI-8226 1640 (Sigma-Aldrich-R8758) including $10 \%(\mathrm{v} / \mathrm{v})$ FBS (BiochromAG, Germany) and 1\% $(\mathrm{v} / \mathrm{v})$ gentamicine (Biological Industries, Israel) $\left(37^{\circ} \mathrm{C}, 5 \% \mathrm{CO} 2\right)$ (Heraus incubator, Henau, Germany).

\section{Cell viability assay:}

Trypan blue (Sigma Aldrich Co. 302643) as a stain was used in procedures for viable cell counting. Trypan blue was diluted at $0.8 \mathrm{mM}$ in PBS. It was mixed with the cells 1:1. In this method, live (viable) and dead (non-viable) cells were counted on hemocytometer ${ }^{7}$.

\section{RNA Is olation}

RNA isolation was made from the examples of dental pulpa cells. One sample was obtained from control group. One sample was obtained from 24 hour-later group. Three different samples were obtained from the groups respectively (Roche RNA isolation kit).

\section{cDNA Syntesis}

viability in dental pulpa cells. No statistical difference was observed ( $p>0.05$ ).

Also gene expression analyses of Nanog and Oct $3 / 4$ gene were $1.72 \times 10-3$ and 0.07 in control, 0.05 and 0.90 in $7 \mu$ proges-
RNAs obtained from dental pulpa cells were used for c-DNA synthesis. C-DNA synthesis was done by using Revert Aid c-DNA synthesis kit. c-DNA' $\mathrm{s}$ were controlled with $2 \%$ agarose gel (Still continuing).

\section{Reverse Transcription (RT-PCR)}

c-DNA' s were used in Nanog, ve Okt3/4 gene expression analyses. The primer lists were found in primer bank [Nanog primers;5'-

TCCCGAGAAAAGATTAGTCAGCA3' (forward), 5'AGTGGGGCACCTGTTTAACTT-3' (reverse), Okt3/4 primers; 5'CTGGGTTGATCCTCGGACCT-

3'(forward), 5'CCATCGGAGTTGCTCTCCA-

3'(reverse)]

(http//pga.mgh.harvard.edu/cgibin/primerbank). RT-PCR conditions: $95^{\circ} \mathrm{C}^{\mathrm{o}} 10^{\prime},, 56^{\circ} 15^{\prime \prime}, 72^{\circ} \mathrm{C} 15^{\prime}$ ' -45 cycle (Roche Light Cycler 1.5). For internal control $\beta$-Actin gene was used [beta-actin housekeeping gene (5'-GTC CCT CAC CCT CCC AAA AG-3' (forward) and 5'GCT GCC TCA ACA CCT CAA CCC-3' (reverse)]. Each reaction is performed as $20 \mu \mathrm{l}(10 \mu \mathrm{l} 2 \mathrm{x}$ SYBR, $5 \mu \mathrm{l}$ c DNA, 0.5 $\mu \mathrm{l}$ primer, $3 \mu \mathrm{d} \mathrm{d} \mathrm{H}_{2} \mathrm{O}$ ). Each sample was studied for 8 times for proper statistical results. Results were analyzed by "Roche Light Cycler1.5 software".

\section{Statistical Analyses}

Mean values and standard deviations were obtained, in cell viability assay. For evaluating the results of RT-PCR analyses, Student T test was used in the comparison of groups.

\section{FINDINGS}

Cell viability assay results were $80 \%$ viable in control, $82 \%$ viable in $7 \mu$ progesterone application, $81 \%$ viable in 14 $\mu \mathrm{l}$ progesterone application, $83 \%$ viable in $21 \mu \mathrm{l}$ progesterone application. Due to our findings, progesterone in different concentrations did not chance the cell

terone treated group, 0.03 and 0.97 in 14 $\mu \mathrm{l}$ progesterone treated group, 0.05 and 2.53 in $21 \mu \mathrm{l}$ progesterone treated group respectively. Statistical difference was observed in gene expression analyses results, due to control $(\mathrm{p}<0.05)$ (Table 1). 
Table 1: Gene expression analyses of Control group and study groups

\begin{tabular}{|c|c|c|c|c|c|c|c|}
\hline & \multicolumn{7}{|c|}{ GENE EXPRESSION LEVELS } \\
\hline GENES & $\begin{array}{l}\text { Control } \\
\text { Group }\end{array}$ & $\begin{array}{c}7 \mu \text { Progesterone } \\
\text { Group }\end{array}$ & $\mathrm{P}$ value & $\begin{array}{c}14 \mu \mathrm{l} \text { Progesterone } \\
\text { Group }\end{array}$ & $\mathrm{P}$ value & $\begin{array}{c}21 \mu \text { Progesterone } \\
\text { Group }\end{array}$ & $\mathrm{P}$ value \\
\hline NANOG & 0,00172 & 0,05 & $\mathrm{p}<0.05$ & 0,03 & $\mathrm{p}<0.05$ & 0,05 & $\mathrm{p}<0.05$ \\
\hline OCT $3 / 4^{3 / 4}$ & 0,07 & 0,9 & $p<0.05$ & 0,97 & $p<0.05$ & 2,53 & $p<0.05$ \\
\hline
\end{tabular}

\section{DISCUSSION}

A viability assay is an assay to determine the ability of organs, cells or tissues to maintain or recover viability. Viability can be distinguished from the all-ornothing states of life and death by use of a quantifiable index between 0 and 1 (or 0 and $100 \%)^{8}$. In this analyses, trypan blue is a vital stain used to selectively colour dead tissues or cells blue. Live cells or tissues with intact cell membranes are not coloured ${ }^{9}$. So, progesterone did not change cell viability in high concentrations. We assume that progesterone did not affect apopitotic pathways on dental pulp cells.

Human dental pulp stem cells, unique mesenchymal stem cells (MSCs) type, exhibit the characteristics of self-renewal and multi-lineage differentiation capacity. As known, Oct4 and Nanog are pluripotent genes. In a recent report, Huang et al. found that concurrent expression of Oct $3 / 4$ and Nanog maintains mesenchymal stem-like property of human dental pulp cells ${ }^{10}$. In our analyses results, progesterone hormone enhances the expression levels of in a dose dependent manner. So, we suppose that progesterone maintains dental pulp cells on $\mathrm{Oct}^{3 / 4} / 4$ and Nanog genes. As known, Oct $3 / 4$ and Nanog are essential for stem cells maintenance ${ }^{11,12}$.

Acknowledgement: Human dental pulpa cells kindly provided by Dr. Deniz TORUN.

\section{REFERENCES}

1. Potdar PD, Jethmalani YD. Human dental pulp stem cells: Applications in future regenerative medicine. World J Stem Cells 2015; 7: 839-51.

2. Kerkis I, Kerkis A, Dozortsev D, Stukart-Parsons GC, Massironi G, Maria S, Lygia VP, Arnold IC, Humberto FC. Isolation and Characterization of a Population of Immature Dental Pulp Stem Cells Expressing OCT-4 and Other Embryonic Stem Cell Markers. Cells Tissues Organs 2006; 184: 105-16.

3. Tekoa L. King; Mary C. Brucker. Pharmacology for Women's Health. Jones \& Bartlett Publishers. 2010; pp. 372-3.

4. Kastner P, Krust A, Turcotte B, Stropp U, Tora L, Gronemeyer $\mathrm{H}$, Chambon P. Two distinct estrogen-regulated promoters generate transcripts encoding the two functionally different human progesterone receptor forms A and B. EMBO J 1990; 9: 160314

5. http://www.1800dentist.com/stud $\mathrm{y}$-reveals-link-between- pregnancy-and-tooth-loss/

6. Köksal G. Östrojen ve progesteronun endometrium hücrelerinde mitojen ile active olan protein kinazlar üzerine etkisi. TC. İstanbul Bilim Ün. Sağlk Bilimleri Enst. Histoloji ve Em- 
briyoloji AD. Yüksel Lisans Tezi, 2009.

7. Coco-Martin JM, Oberink JW, van der Velden-de Groot TA, Beuvery EC. Viability measurements of hybridoma cells in suspension cultures. Cytotechnology. 1992; 8: 57-64.

8. Pegg DE. Viability assays for preserved cells, tissues, and organs. Cryobiology 1989: 26: 212-31.

9. Strober W. Trypan blue exclusion test of cell viability. Curr Protoc Immunol. 2001; Appendix 3: Appendix 3B.

10. Huang CE, Hu FW, Yu CH, Tsai LL, Lee TH, Chou MY, Yu CC. Concurrent expression of Oct4 and Nanog maintains mesenchymal stem-like property of human dental pulp cells. Int $\mathbf{J}$ Mol Sci 2014; 15: 18623-39.

11. Kregel S, Szmulewitz RZ, Vander Griend DJ. The pluripotency factor Nanog is directly upregulated by the androgen receptor in prostate cancer cells. Prostate 2014; 74: 1530-43.

12. Shen SW, Song HY. Progesterone promotes propagation and viability of mouse embryonic stem cells. Sheng Li Xue Bao 2009; 61: 431-8. 